\title{
SYSTEM BASIS FOR STUDYING THE INTERACTION OF NATIONAL AND INDIVIDUAL HUMAN CAPITAL
}

\author{
Tetiana FONAROVA ${ }^{1}$ \\ National Metallurgical Academy of Ukraine, Ukraine \\ Vladimir CHERNYAK ${ }^{2}$ \\ National Mining University, Ukraine
}

\begin{abstract}
The objective of the paper is the systematisation of features of the display and study of human capital assets, depending on the level, where it functions and is transformed from one form to another, as well as the definition and evaluation of the basic cost parameters that reproduce the characteristics of this capital at different levels. Methodology. The study is built on the provisions and principles of the system approach and justified quantitative calculations of indicators of individual human capital carried out on the basis of statistics development of the Ukrainian economy during the period from 2002 to 2016. Results of the studies have shown that while the cost of individual human capital, having a generally positive trend of changes, increased almost fifteen times from 2002 to 2016 , the efficiency of its use had a stable dynamics, changing annually by $18 \%$ at most. At the same time, the cost of using human capital did not exceed the bank lending rate. Practical implications. The final provisions and results of the study can be used to formulate a methodology for assessing human capital in the management of costs and personnel of enterprises, organizations, and institutions. Value/originality. The data obtained provide a better understanding of the processes of development and realization of the human potential of social and economic entities of any scale and national economy, as well as enterprises of Ukraine in particular.
\end{abstract}

Key words: human capital, systematisation, individual human capital, national human capital, price and efficiency of use.

\section{JEL Classification: 015, E24}

\section{Introduction}

At present, the field of research on the problem of "human capital assets" has expanded from a narrow issue of investment in the development of personnel to supereconomical scales and attracts the attention of both economists and specialists in sociology, psychology, management, philosophy of science and the like. Accordingly, there are certain differences in approaches to formulating the definitions of this category. Labour resources, human resources, work force, personnel, human capital, labour potential, employment potential, workforce capacity, intellectual potential - are a complex of concepts, which today are most often used in scientific literature in dealing with the need to assess the effectiveness of the use of human capital. The lack of clear definitions and boundaries for different classification groups, as well as the possibility of the flow of human capital from one form to another, necessitate the search for appropriate classification characteristics and methods for distinguishing its varieties. The issue of who and what price to pay for the use of human capital, as well as the issue of the effectiveness of its functioning and development, is still open. The objective of the paper is the systematisation of features of the display and study of human capital assets, depending on the level where it functions and is transformed from one form to another, as well as the definition and evaluation of the basic cost parameters that reproduce the characteristics of this capital at different levels. The basis for the quantitative assessment was the indicators of the development of the economy of Ukraine in the period from 2002 to 2016.

\section{The modern basis of research on human capital}

The modern "theory of human capital" is the direction of economic science, in which the human component of economic systems of different scale is considered in terms of value and price and differs inherently in three levels (Vasilchenko, Grinenko, Grishnova, \& Kerb, 2005):

\footnotetext{
Corresponding author:

${ }^{1}$ Department of Management, National Metallurgical Academy of Ukraine.

E-mail: fonarevat@ukr.net

${ }^{2}$ Department of Management, National Mining University.

E-mail: vi_chernyak@ukr.net
} 
- on the personal level, the human capital is the knowledge and skills that a person has received through education, training, practical experience (using his natural abilities), and through which he or she can provide valuable production services to other people. At this level, human capital can be compared to other types of personal property (material possessions, money, securities) that yields income, and we call it personal or private human capital;

- on the microeconomic level, human capital is the cumulative qualifications and professional capabilities of all employees of the enterprise, as well as the company's achievements in the effective organization of labour and staff development. At this level, the human capital is associated with the production and commercial capital assets of the enterprise, thus the profit is derived from effective management of all types of capital assets;

- on the macroeconomic level, human capital includes the accumulated investments in such areas as education, training and retraining, vocational guidance and job placement service, rehabilitation, etc., is a substantial part of the national wealth of the country, and we call it the national human capital. This level includes all the sum of human capital of all companies and all citizens (without double counting), as well as national wealth includes the wealth of all citizens and all legal entities.

At the same time, in world practice, there are three principal approaches to the accounting and evaluation of human capital (Resler, 2015):

1) cost-based, according to which human capital is formed on account of investing in people (education, professional training, health, etc.);

2) output-based, according to which human capital is defined as the ability to use the acquired knowledge, skills, talents, abilities of people in economic activity, and to get income or capital gains from such use;

3) social-based, which defines human capital as a reserve of abilities, health, knowledge, skills, experience, motivation, the mobility of individuals.

Each socio-economic entity, due to the nature of its activities and the individuality of the organizational structure can independently determine its indicators system to calculate the cost of human capital and, on this basis, build personnel development strategy.

At the same time, modern developments do not provide for the study of clear relationships between the levels and the possibilities of transforming the capital from one level to another. The issues of determining the price and the effectiveness of the use of human capital remain disputable, which can be illustrated by a number of facts of the kind, for example, given in the Revolutionary Wealth book (Toffler, Toffler, 2008): "The USA annually spends 400 billion dollars on education from preschool to secondary inclusive, i.e. about 7,000 dollars per student. However, 60 per cent of secondary school pupils cannot read well enough to study the textbooks, one-third of school leavers have no mathematics knowledge, necessary for a novice carpenter, and almost a third of young people cannot show the Pacific Ocean on the map."

\section{Systematization of levels of human capital}

The problem of multi-levelling is mainly determined either by the absence or incorrect use of the system approach, ignoring two system factors:

1) Systematicity is the result of a manifestation of "Thinking" as a property of Consciousness, and not the property of the entire world as a whole. And according to the phases of Consciousness development, it is necessary to distinguish: the Systems of Individual Consciousness (SIC), Systems of Group Consciousness (SGC), and Systems of Mass Consciousness (SMC). And the preservation of such a triune in the analysis of socioeconomic phenomena and processes is a precondition for the systemic approach implementation.

In the "spaces of measures and values" of each level, "own" semantic constructions (syntagmas) are formed, the matching or mismatching of which in the overall interrelation determines the effectiveness of the cognitive activity.

Generally, sustainable systems of particular objects are generated only during large time intervals - e.g. in the course of any professional activity. At the same time, in relation to other, temporary impulses of life activity, it is often difficult or even impossible to consider effective system thinking.

We entangle our life activity in a network of laws (norms, rules), forgetting that these laws are not "the very essence" of things, but only "measures and meanings," which we attribute to this essence. We form these "measures and meanings" within the framework of human perception, accessible to us. Those are the "measures and meanings", which are "convenient" (because it is customary) to operate for our human thinking.

2) All changes in any community take place under the influence of: a) natural evolutionary mechanisms of development (self-organization); b) socially conditioned mechanisms of development.

The social mechanism of development functions on the basis of operating with "senses" ("measures and meanings", "syntagmas"). The semantic meaning these individuals and groups assign to the surrounding objects and phenomena, and the degree to which these values match in different dimensions (SIC, SGC, SMC) determine the "effectiveness" of the development of society and of a particular individual in it. The "meaning" of any thing, process or phenomenon is subjective. The object itself exists separately as an attractor, and its meaning, attributed by us, the "humans" - exists on its own as well. A purposeful change of things, processes, and phenomena is the management, and a purposeful alteration of their "meaning" is the manipulation. What 
we now call management is actually "management + manipulation".

Therefore, the designed criteria for the development of a Community, along with "artificial" socio-economic indicators must include the ones reflecting the natural essence of the Human itself. Based on these criteria, the "value parity" of various "subjects of knowledge" is formed in the social field of "research and practice" relationships of the members of society.

The same relationship is established in all spheres of "socio-psychological" interactions of the members (subjects) of society. As a result, the "flows of values" are formed in the society (SMC), exerting a positive or negative influence on the development of affective, cognitive, and conative abilities of the SIC.

The process of operating the "senses" itself takes place in the three-dimensional space of states of consciousness: individual, group, and mass. And each axis of this space represents "its own folded system": three-dimensional (SIC), five-dimensional (SGC), and eight-dimensional (SMC). The natural process of the consciousness evolution is inherently a consistent increase in the dimensionality of the space of its states. Moreover, one should also take into account that the logic and "technique" of operating "senses" in the systems of individual, group, and mass consciousness are different.

The SIC-SGC-SMC chain on a large scale of time is a part of the natural evolutionary process, carried out on the basis of natural mechanisms of self-organization. Within the same time interval and a specific social structure, the actions of particular individuals and groups act as the organizational mechanism of development. The "systems of mass consciousness" have become a "product" of their activities and through the feedback channels they are gaining the ability to influence behavioural algorithms of other individuals and groups.

When the direct connection (SIC-SGC-SMC) is the dominant influence on the object, then we can talk about the "object management". If, when trying to influence the individual, the feedback (SMCSGC-SIC) is the top priority, it is nothing else but "social manipulation". The fact is that for an individual there is no direct connection with the society, he or she identifies himself or herself with the "mass" only through his/her role and place in the "group". At the same time, the motivator for group behaviour is the need to occupy such an "energetic position" that corresponds to the psychological type of the given individual at the current time.

From the above provisions, it should be understood that no matter, which level of human capital we plan to explore, the basic structural element must always be the "individual human capital", which has its value and efficiency of use, depending on which socio-economic group it belongs.

\section{SMC, the national human capital level}

Certainly, the evaluation of human capital indicators at each of the levels has its own specific features, but their overall scale and quantitative characteristics define the level of national human capital.

To assess the national human capital, the Human Potential Index and the Value of National Human Capital are currently used. The Human Potential Index (HPI) of a country or region is calculated by three indicators: GDP (or GRP), life expectancy and literacy of the population. The value of national human capital (VNHC) of the countries of the world is estimated by specialists of the World Bank using the cost-based method. Estimates of the components of the costs of the state, families, entrepreneurs, and various funds are used. They allow determining the current annual expenses of the society for the reproduction of human capital.

Meanwhile, the specialists - users of this information, note certain difficulties in the comparative evaluation of VNHC of countries with unequal levels of development. The human capital of the underdeveloped country and the developed country has substantially different productivity per capital unit, as well as quite different quality. Partially this problem is removed by the Global Human Capital Index (GHCI), which is published annually as a part of the report at the World Economic Forum. However, as a relative indicator, the index does not allow for the projection on the individual and group levels of human capital.

When investigating this issue, the Russian scientist Y.A. Korchagin (Korchagin, 2011) suggested a method for determining the value of national human capital. He introduced the concept of the accumulated value of human capital $(A V H C)$, which can be calculated by the formula suggested as follows:

$$
A V H C=G D P \times I_{c h c}^{e} \times S h_{i v} \times m,
$$

where GDP - the country's gross domestic product;

$I_{c h c}^{e}-$ the index of the effectiveness of the country's human capital;

$S h_{i v}$ - the share of innovative economy in the country; $m$ - the number of years in the period for which the $A V H C$ is calculated.

To calculate the index of the effectiveness of human capital, Y.A. Korchagin uses such data of international organizations as the Index of Economic Freedom (IEF), the index of the quality of life of the population (QL), the index of human potential development (HDI); as well as the index of science and synergetics; index of inflow of HC (human capital) from the outside of the subject (outflow from it); the quality index of the accumulated $\mathrm{HC}$ (calculated by the group of indicators and indices), the index of effectiveness of the elite and the shadow economy; index of the raw economy, reflecting the type of predominating raw materials economy and the dependence of the industrial and resource-based economy country on the raw materials exports. 
In this interpretation, the indicator of national human capital allows us to form its projection on the system level of individual human capital.

\section{SIC, the level of individual human capital}

Relying on the logic of assessing the value of national human capital, we put it as follows:

$V I H C=G D P_{1} \times I_{c h c}^{e} \times m$,

where: VIHC is the value of individual human capital; $G D P_{1}$ - is the gross domestic product per capita in Ukraine;

$m$-is the work experience of an individual employee;

$I_{c h c}^{e}-$ is the index of the effectiveness of individual human capital.

For the index of individual human capital effectiveness, we put it as follows:

$$
I_{\text {chc }}^{e}=\frac{\text { Gross Value Added GDP }}{\text { available income ofpopulation }} \text {. }
$$

Based on the statistical data, we can also calculate the average value of use (credit granting) in the national economy of individual human capital $T_{\%}^{c p}$, which is expressed as a percentage of its value:

$$
T_{\%}^{c p}=\frac{\cos \text { ts of employees labour payment }}{\text { products manufacture }} \times 100 \% \text {. }
$$

Using statistic data of the Office for National Statistics of Ukraine, the calculations are based on the obtained (2-4) formulas. The results of calculations are provided in Table 1. When analysing the dynamics of the calculated indicators of the individual human capital assessment (see Fig. 1, 2), a special attention should be paid to changes in the index of the effectiveness of individual human capital and the value of individual human capital.

The diagram in Figure 1 shows that while the cost of individual human capital, with a generally positive trend of change, increased almost 15 times between 2002 and 2016, the effectiveness of its use has a stable dynamics, changing annually by $18 \%$ at most.

If individual human capital is considered as the property of the employee, the market value of his/ her labour and the income from the investments in his/her development by the enterprise constitute the price that the enterprise pays for the possibility of using (borrowing) the individual human capital and, according to the theory of interest, is defined as the share (percentage) of the principal amount of capital.

At this point, attention should be paid to the fact that the interest, as a price of monetary capital, is an irrational form of price, quite contrary to the concept of the commodity price. Thus, the price of the goods corresponds to its cost (i.e. economic costs). The price of borrowed capital does not express its value but the cost of the service, provided by the borrowed capital at the time of its participation in the production process, as its time factor.

Table 1

\begin{tabular}{|c|c|c|c|c|c|c|c|c|}
\hline Year & $\begin{array}{c}\text { Issue }{ }^{*} \\
\text { million UAH }\end{array}$ & $\begin{array}{c}\text { Gross value } \\
\text { added *. } \\
\text { million UAH }\end{array}$ & $\begin{array}{c}\text { Including } \\
\text { wages } \\
\text { of hired } \\
\text { employees*, } \\
\text { million UAH }\end{array}$ & $\begin{array}{c}\text { Available } \\
\text { income of the } \\
\text { population*, } \\
\text { million UAH }\end{array}$ & $\begin{array}{c}G D P_{1}^{*}, \\
\text { thousand } \\
\text { UAH / } 1 \\
\text { person }\end{array}$ & $I_{c h c}^{e}{ }^{* *}$ & $\begin{array}{c}\text { VIHC } \\
\text {, excluding } \\
\text { working } \\
\text { experience } \\
\text { **, thousand } \\
\text { UAH } \\
\end{array}$ & $T_{\%}^{c p}{ }^{* *}, \%$ \\
\hline 2002 & 504,008 & 201,194 & 103,117 & 141,618 & 4,855 & 1.421 & 6,656 & 20.46 \\
\hline 2003 & 603,704 & 240,217 & 122,188 & 162,578 & 5,801 & 1.478 & 8,261 & 20.24 \\
\hline 2004 & 809,988 & 313,046 & 157,450 & 212,033 & 7,535 & 1.476 & 10,738 & 19.44 \\
\hline 2005 & 995,630 & 388,601 & 216,600 & 298,275 & 9,709 & 1.303 & 12,210 & 21.76 \\
\hline 2006 & $1,182,179$ & 474,123 & 268,631 & 363,586 & 12,076 & 1.304 & 15,166 & 22.72 \\
\hline 2007 & $1,565,055$ & 634,794 & 351,936 & 470,953 & 16,150 & 1.348 & 20,887 & 22.49 \\
\hline 2008 & $2,072,172$ & 824,176 & 470,464 & 634,493 & 21,419 & 1.299 & 26,622 & 22.70 \\
\hline 2009 & $1,955,685$ & 796,481 & 451,343 & 661,915 & 20,564 & 1.203 & 23,864 & 23.08 \\
\hline 2010 & $2,594,833$ & $1,120,585$ & 540,651 & 847,949 & 24,798 & 1.321 & 32,758 & 20.84 \\
\hline 2011 & $3,147,953$ & $1,349,178$ & 636,722 & 988,983 & 29,980 & 1.364 & 40,899 & 20.23 \\
\hline 2012 & $3,347,592$ & $1,459,096$ & 736,495 & $1,149,244$ & 32,480 & 1.270 & 41,237 & 22.00 \\
\hline 2013 & $3,375,851$ & $1,522,657$ & 763,187 & $1,215,457$ & 33,965 & 1.253 & 42,549 & 22.61 \\
\hline $2014^{* *}$ & $3,558,223$ & $1,586,915$ & 734,943 & $1,151,656$ & 36,904 & 1.278 & 50,852 & 20.65 \\
\hline $2015^{* *}$ & $4,488,398$ & $1,988,544$ & 777,646 & $1,330,089$ & 46,413 & 1.495 & 69,290 & 17.33 \\
\hline $2016^{* *}$ & $4,984,600$ & $2,358,971$ & 986,770 & $1,519,574$ & 55.557 & 1.552 & 86,277 & 19.80 \\
\hline
\end{tabular}

Calculation of value indices of individual human capital in Ukraine, thousands, UAH

${ }^{*}$ Data of the Office for National Statistics of Ukraine

** (excluding the temporarily occupied territory of the Autonomous Republic of Crimea and the city of Sevastopol, to 2014-2015 - also without taking into account the ATO territory)

*** Author's calculations 
When the individual income (Dind) of an individual worker is defined as a result of fulfilment (that is, the capital) of his/her human potential, through a tariff rate $(T R)$ or official salary plus additional income (AI) in the form of various kinds of rewards, extra payments, bonuses, etc., then the following formula can be used for the calculation of individual human capital value:

$$
V I H C \times T_{\%}=T R+A I
$$

where $\mathrm{T} \%$ is the price of using (credit granting) of individual human capital expressed as a percentage of its value.

The analysis of the price of using individual human capital (i.e. a conventional credit rate, at which the employee lends his/her human capital to the enterprise) shows (see Fig. 2) that it roughly corresponds to the current rates, at which domestic banks lend to our enterprises. Therefore, the estimated value of individual human capital at the end of 2016 was $19.8 \%$ compared to the average bank rate, which at the same time period reached $25.6 \%$ per annum.

Thus, we represented the basic parameters of individual human capital, which determine the value and effectiveness of its use, and also allow their projection to higher (group and mass) levels of its research.

\section{Conclusions}

Methodological basis of modern human capital research relies on the combination of various provisions, among which the most important is the concept of multilevel nature of its structure, as well as the assessment of value and effectiveness of its use.

The above provisions of the system approach demonstrate that irrespective of the level of human capital to be explored, the basic structural element must always be the "individual human capital" with its value and efficiency of use, depending on the socio-economic group it belongs to.

Based on statistical data of Ukraine's economy, the methods of determining the main parameters of individual human capital, establishing the value and efficiency of its use, have been provided.

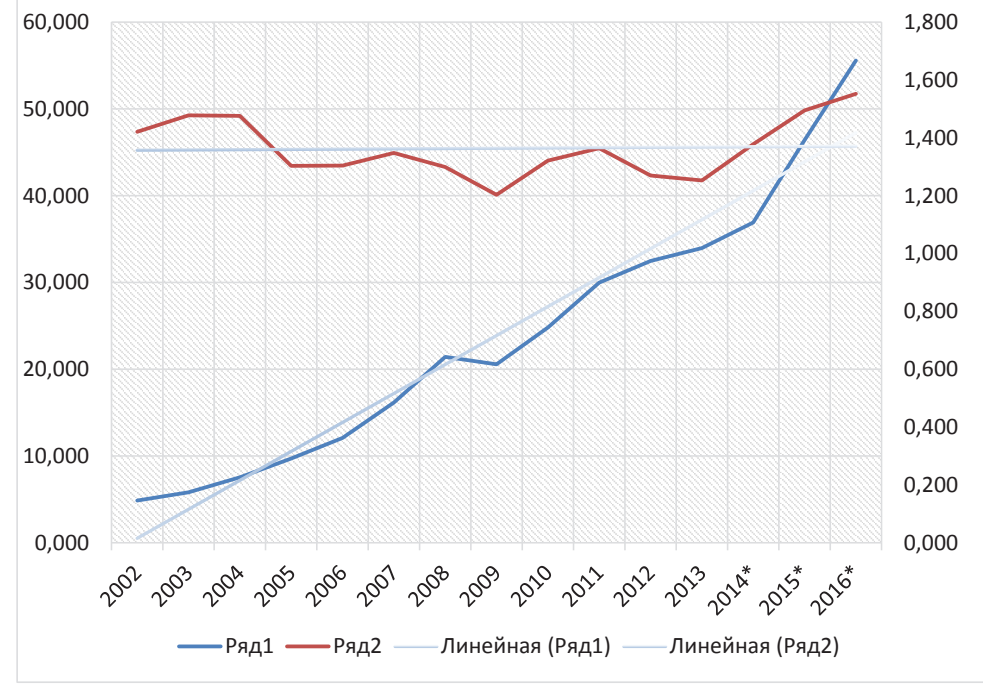

Fig. 1. The dynamics of value (line 1) and effectiveness (line 2) of the human capital in Ukraine for 2002-2016 (* excluding the temporarily occupied territory of Crimea and Sevastopol, to 2014-2015 - also without taking into account the ATO territory)

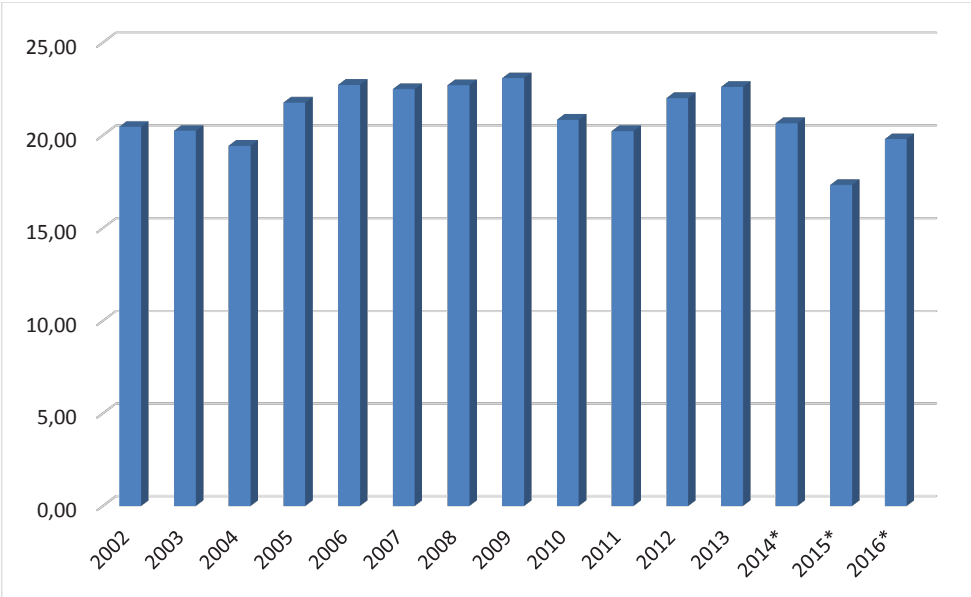

Fig. 2. Dynamics of the prices of using the individual human capital in Ukraine for 2002-2016 ( ${ }^{*}$ excluding the temporarily occupied territory of the Autonomous Republic of Crimea and the city of Sevastopol, to 2014-2015 also without taking into account the ATO territory)

Results of the calculations have shown that while the value of individual human capital, having a generally positive trend of changes, increased almost fifteenfold from 2002 to 2016, the efficiency of its use had a stable dynamics, changing annually by $18 \%$ at most. At the same time, the price of using human capital did not exceed the bank lending rate.

\section{References:}

Korchagin Y. (2011). Efficiency of the national human capital: the method of measurement. Retrieved from: http://www.lerc.ru/?part=articles\&art=3\&page $=29$

Resler M.V. (2015). Human capital as an object of accounting. Scientific Herald of the International Humanitarian University. Series: Economics and Management, 12, 231-234.

Toffler A., \& Toffler H. (2008). Revolutionary Wealth. M.: AST; AST MOSKVA, p. 306.

Vasilchenko V., Grinenko A., Grishnova O., \& Kerb L. (2005). Management of labor potential. KNEU, 403 p. Retrieved from: http://buklib.net/books/31304/ 


\section{Татьяна ФОНАРЕВА, Владимир ЧЕРНЯК}

\section{СИСТЕМНЫЕ ОСНОВАНИЯ ИЗУЧЕНИЯ \\ ВЗАИМОСВЯЗИ \\ НАЦИОНАЛЬНОГО} И ИНДИВИДУАЛЬНОГО ЧЕЛОВЕЧЕСКОГО КАПИТАЛА

Аннотация. Целью работы является систематизация особенностей проявления и изучения человеческого капитала в зависимости от того уровня где он функционирует и трансформируется из одной формы в другую, определение и оценка основных стоимостных параметров, которые воспроизводят характеристики этого капитала на разных уровнях. Методика. Исследование построено на положениях и принципах системного подхода и обосновывается количественными расчетами показателей индивидуального человеческого капитала, проведенных на основе статистических данных развития экономики Украины в период с 2002 по 2016 годы. Результаты исследования показали, что в то время, как стоимость индивидуального человеческого капитала, имея в целом положительную тенденцию изменений, в период с 2002 года по 2016 год увеличилась почти в 15 раза, эффективность его использования имела устойчивую динамику, ежегодно изменяясь не более чем на 18 \%. При этом цена использования человеческого капитала не превышала банковской ставки кредитования. Практическое значение. Конечные положения и результаты исследования могут быть использованы для формирования методики оценки человеческого капитала в управлении стоимостью и персоналом предприятий, организаций и учреждений. Значение/оригинальность. Полученные данные способны обеспечить лучшее понимание процессов развития и реализации человеческого потенциала социально-экономических субъектов любого масштаба и национальной экономики, а также предприятий Украины, в частности. 